\title{
REDEFINING THE CLASSIC CONCEPT OF THE COURT? -RESPONSES TO THE CORPORATE SOLVENCY PROBLEM IN THE ONGOING COVID-19 CRISIS*
}

\author{
Dejan Bodul, PhD \\ Faculty of Law Rijeka \\ Hahlić 6, Rijeka, Croatia \\ dbodul@pravri.hr
}

\begin{abstract}
The coronavirus pandemic is pushing large number of firms towards insolvency by dramatically changing consumption patterns and business operations. The first wave of liquidity-focused policy responses (Act on Intervention Measures in Enforcement and Insolvency Proceedings for Duration of Special Circumstances) prevented or delayed more severe consequences for the corporate sector. While some liquidity support is still needed, the crucial issue that must be tackled now is that of corporate solvency. This paper addresses the role of the Financial Agency (hereinafter: FINA), which, as a legal entity with public authority, has (in)appropriate legal authority in bankruptcy proceedings over the rights of entities. As in the previous paper, a multidisciplinary scientific approach is advocated, which should contribute to the consideration of various aspects of the relationship between FINA, the state, the judiciary and the current tendency of Dejudicijalization.
\end{abstract}

Keywords: judiciary, court, the role of FINA, reforms, informal bankruptcy

\section{DEFINING LEGAL TERMS}

Having in mind the complexity and topicality of the problem we are analysing, we consider it important to make a terminological distinction ab intio in order to make it clear what is meant by the term's - "court", "dejudicialization" and "FINA".

This paper was funded under the project line ZIP UNIRI of the University of Rijeka, for the project ZIP-UNIRI-130-7-20". 
Pursuant to the provisions of the Law on Courts, ${ }^{1}$ a court is defined as a body of state power that exercises judicial power independently within the scope and jurisdiction determined by law (Art. 2). However, taking into account the fact that the principle of precedent and thus jurisprudence as a formal source of law is affirmed through the jurisprudence of the ECHR, the term "court" in Art. 6. par. 1 of the Convention for the Protection of Human Rights and Fundamental Freedoms with Protocols ${ }^{2}$ shouldn't necessarily be understood as a court "in the classical sense", which is integrated into the standard judicial apparatus of a country (Art. 2 LC), but also the body that has jurisdiction on the basis of legal rules and has a possibility to conduct the procedure in the manner prescribed by law. Of course, such a body must also meet a number of criteria, primarily the criteria of independence and impartiality, the manner of appointment and the duration of the mandate, the existence of guarantees against external pressure and the question of whether that body gives the impression of independence. ${ }^{3}$

In this context, where are talking of dejudicialization for the protection of civil rights and obligations. Namely, there is no doubt that the legal systems of modern countries are exposed to reform processes, and one of them is dejudicialization. For the purposes of this paper, we can define dejudicialization as the process of transferring certain tasks of the judiciary to non-judges, in this case to Financial Agency (hereinafter: FINA).

FINA has been operating under this name since 2002, as the successor of the Payment Operations Bureau and the Social Accounting Service. According to its legal form, FINA is a legal entity with public authorities for which registration is prescribed by a special law, and the sole founder is the Republic of Croatia. The special law according to which it was established is the Law on Financial Agency, ${ }^{4}$ and the main activity is financial intermediation through market activities. Within these activities, FINA is a State partner in a number of projects. When it comes to bankruptcy proceedings, more significant role was given to FINA through the provisions of ZFPPN. ${ }^{5}$ However, in practice, although the adoption of the ZFPPN significantly changed the bankruptcy procedure in the Republic of Croatia, in its three-year practical application a number of problems were observed in the interpretation and effects of certain provisions and institutes, which was eliminate

Official Gazette No. 28/13, 33/15, 82/15, 82/16, 67/18, 126/19, 130/20. hereinafter: LC.

Official Gazette No. 18/97, 6/99, 14/02, 13/03, 9/05, 1/06, 2/10, hereinafter: Convention.

3 Bodul, D., Grbić, S., O medusobnoj komplementarnosti pojmova „sud“ $i$ „javni bilježnik“ u praksi Europskog suda za ljudska prava, Javni bilježnik, 2014, No. 40, p. 35 et seq.

4 Official Gazette No. 117/01, 60/04, 42/05.

5 Law on Financial Operations and Pre-Bankruptcy Settlement, Official Gazette No. 108/12, 144/12, 81/13, 112/13, 71/15, 78/15, hereinafter: ZFPPN. 
by the new $\mathrm{BA}^{6}$ in 2015 . Nevertheless, from doctrinal point of view the objection remains. Namely, FINA should be either a public service, taking care of the public good and the interests of all, or a private organization that takes care of its own profit. If FINA wants to operate in the market, then we should open that market to everyone on equal terms. On the other hand, if FINA is a public service, then the pricing policy of its activities should be shaped by a public debate on how to optimize costs for everyone's benefit. Instead, internal meetings discuss how FINA, as an enforcement monopolist, can make the biggest profit just for itself. ${ }^{7}$

\section{METHODOLOGY OF WORK, WORK GOAL AND REVIEW OF RELEVANT LITERATURE}

The subject of the analysis are the current norms related to the position of FINA in bankruptcy proceedings, having in mind the possible consequences of incomplete and inadequate regulation on the rights and interests of the participants. Therefore, in addition to the legal analysis of FINA's position in bankruptcy proceedings, as it is under the existing (valid) legal framework (de lege lata), this paper also includes the question of what that position should be with regard to the requirements of practice (de lege ferenda). This provides a picture of the relationship between legal regulations and practice, and shows the shortcomings of the current legal standardization of FINA's position in bankruptcy proceedings. Methodologically, for the purposes of the analysis, telephone interviews were conducted among representatives of the bodies responsible for the implementation of bankruptcy proceedings. Conducted interviews of targeted respondents serve to further verify the credibility of the results of this analysis. The collected data indicate practical problems in the implementation of certain legal solutions in the first period of application of the new BA legislation. The perspective of individual interviewees is based on knowledge and experience gained in the practice of applying previously applicable legislation, which is certainly an important factor in assessing the improvement, but also the degree of optimization of the existing legal framework of legal protection in bankruptcy proceedings.

The aim of this analysis is to find an answer to the question of whether the existing legal framework governing FINA's position in bankruptcy proceedings meets the requirement of effective legal protection. Therefore, the analysis is based not only

Bankruptcy Act, Official Gazette No. 71/15, 104/17, hereinafter: BA.

Blanchard, O.; Philippon, T.; Pisani-Ferry, J., A New Policy Toolkit Is Needed as Countries Exit COVID-19 Lockdowns, Peterson Institute for International Economics (PIIE) 20-8, June, 2020; Hodbod, A.; Hommes, C.; Hube, S. J.; Salle, I., Avoiding zombification after the COVID-19 consumption game-changer, VoxEU.org, 21 December, 2020.; Boggs, P., Impact of COVID-19 on Insolvency Laws: How Countries Are Revamping Their Insolvency and Restructuring Laws to Combat COVID-19, 2020. 
on practical problems but on detecting possible problems that could complicate bankruptcy proceedings.

In the Republic of Croatia, there are, perhaps, hundreds of scientific texts that deal with extensive and complex issues of bankruptcy regulations (Dika, M., Garašić, J., Bodul, D., Eraković, A. and Čuveljak, J.) It is a relatively modest number of monographs in the field of bankruptcy, ${ }^{8}$ as opposed to capital works, scientific articles that exist in German bankruptcy law, or U.S. law. ${ }^{9}$ Yet in recent years, an increasing number of studies have analysed the economic and legal effects of liquidation and reorganization bankruptcy proceedings. However, the benefits of participation of FINA in (pre-)bankruptcy proceedings remain unclear in the existing literature. From what has been said, we notice that the existing literature does not provide an answer, as well as useful explanations and appropriate approaches. Therefore, this research will present systematic and scientifically based analysis of role of the FINA in (pre-)bankruptcy proceedings.

\section{ANALYSIS OF THE ROLE OF FINA IN THE BANKRUPTCY LAW}

Pressure for the reform of pre-bankruptcy settlements from the ZFPPN, i.e. for a stronger role of the court, was also exerted by the application of Art. 6. of the Conventions. ${ }^{10}$ Namely, the practice of the ECHR indicates that Art. 6, par. 1 applies to bankruptcy proceedings, ${ }^{11}$ so the first dilemma regarding the very legitimacy of the dejudicialisation process through the pre-bankruptcy settlement model is the fact that bankruptcy legal protection must be within the jurisdiction of the body referred to by the Convention as a tribunal, and today only a court has those properties in positive law. This resulted in the "deletion" of legislative decisions according to which FINA de facto and de jure decided in pre-bankruptcy settle-

8 Dika, M., Insolvencijsko pravo, Pravni fakultet, Zagreb, 1998; Eraković, A., Stečajni zakon s komentarom i primjerima, Računovodstvo, revizija i financije Plus, Zagreb, 1997.

9 Group of Thirty, Reviving and Restructuring the Corporate Sector Post-Covid: Designing Public Policy Interventions, Group of Thirty, Washington D.C. Marsh, 2020; Ministry of Law Singapore, Simplified Insolvency Programme, October 5, 2020; Wyman, O., Building up immunity of the financial sector: Policy actions to address rising credit risk and preserve financial stability, August, 2020; UK Government, Corporate Insolvency and Governance Bill 2020: factsheets, UK Government Department for Business, Energy and Industrial Strategy (BEIS) and The Insolvency Service, June 1, 2020.

10 For more, Omejec, J., Konvencija za zaštitu ljudskih prava i temeljnih sloboda u praksi Europskog suda za ljudska prava, strasbourški acquis, Zagreb, Novi informator, 2013, p. 1297 et seq.

11 Arg., S.p.r.l. ANCA and Others v. Belgium, decision, 10 December 1984, Decisions and Reports 40, Interfina and Christian della Faille d'Huysse v. Belgium, decision, 4 May 1987, no. 11101/84, Ceteroni v. Italy, judgment, 15 November 1996, Reports of Judgments and Decisions 1996-V, Bassani v. Italy, judgment, 11 December 2003, no. 47778/99, Capital Bank AD v. Bulgaria, Judgment, 24 November 2005, no. $49429 / 99$ and Sukobljević v. Croatia, Judgment, 2 November 2006, no. 5129/03. 
ment proceedings in ZFPPN. The new solution indicates the independence of the court, which means that the Court is a special type of state authority to which special trial rules apply, and FINA serves as its "assistance" in the proceedings.

\subsection{The role of FINA in pre-bankruptcy proceedings}

One of the major changes in the BA is the implementation of Chapter II, i.e. the provisions on pre-bankruptcy settlement, which were transferred from the ZFPPN to the BA as a pre-bankruptcy procedure. The pre-bankruptcy procedure (hereinafter: PP) itself is designed for those entities that are essentially financially sound and have a business perspective, but their main obstacle to further progress is an unfavourable balance sheet, with the possibility of economically realistic negotiations with their largest creditors to ensure the inflow of capital that is a necessary precondition for their development.

\subsubsection{General provisions}

The bodies of the PP are the single judge and the commissioner/bankruptcy manager (Art. 21 of the BA), and FINA is the technical and administrative service of the court (Art. 44 of the BA), whose work is constantly monitored by the court (Art. 45 of the BA). The body conciliation council no longer exists in the new BA but only FINA, and apart from such a linguistic form the difference is much deeper. Namely, in the PP there is only real and territorial jurisdiction of the commercial court in whose territory the debtor's registered office is located, so the proposal for opening the PP is submitted to the court (Art. 16 of the BA), no longer to the FINA (there is no longer an administrative court, so now everything is decided by the competent commercial court, i.e. on appeal by the High Commercial Court of the Republic of Croatia). In accordance with the above, the logical novelty is that the rules of civil procedure (Art. 10 of the BA) are appropriately applied in the PP before the Commercial Court, in accordance with the Civil Procedure Act, ${ }^{12}$ as opposed to the previous appropriate application of the General administrative proceedings under pre-bankruptcy settlement proceedings before FINA. Moreover, the court in PP, as we pointed out, supervises the work of FINA and is authorized to give instructions and request notifications or reports on actions taken in the proceedings. ${ }^{13}$

12 Official Gazette No. 53/91, 91/92, 112/99, 88/01, 117/03, 88/05, 2/07, 84/08, 96/08, 123/08, 57/11, 148/11, 25/13, 89/14, 70/19.

13 See, Ordinance on the list of Financial Agency units and areas of their competence, Official Gazette No. 106/15. 


\subsubsection{Powers and duties of FINA in pre-bankruptcy proceedings}

In the PP, FINA has certain powers and duties that are broader than in bankruptcy proceedings. It issues certificates on the existence of pre-bankruptcy reasons, receives claims, receives statements from debtors and commissioners on reported claims, compiles a table of reported claims and a table of disputed claims, and receives disputed claims. A particularly important role of FINA is to deal with the bases for payment after the opening of the PP, then after the suspension of the PP and finally after the decision on the confirmation of the pre-bankruptcy agreement becomes final (legal consequences of opening the PP) (Art. 34, 36, 38, $40,41,42,43,44,45,61,64,69,70$ and 71 . of the BA). The question arises, however, whether the legislator had to delegate to FINA tasks related to filed claims instead of keeping then in the hands of the bankruptcy judges and the bankruptcy trustees? These tasks could certainly have been performed by the commissioner instead of FINA, but then several questions arise. First, the appointment of a commissioner in each PP is not mandatory, but depends on the court's assessment of the need for his appointment (Art. 33, par. 2 of the BA) and, second, the sufficiency of the advance of HRK 5,000.00 to cover all costs of this procedure (Art. 28 of the BA). Namely, the Decree on Criteria and Manner of Calculating and Paying Remuneration to Bankruptcy Trustees ${ }^{14}$ stipulates that the PP Commissioner is entitled to a one-time award for work performed in the PP in the amount of HRK 3,000.00 to 20,000.00 HRK gross (Art. 3 of the BA). It is questionable whether the court will force the debtor to bear higher costs than the upper limit of HRK 5,000.00 only because of the costs of the Commissioner. Furthermore, the trustee cannot count on covering the costs from the Bankruptcy Proceedings Fund, which is strictly intended to cover the costs of the bankruptcy proceedings (Art. 111. of the BA). This means, given the quantity and quality of processing that the legislator has opted for FINA, which undoubtedly has the capacity to meet all PP requirements with a reasonable price of service fee of HRK 760.00 plus value added tax.

\subsubsection{The role of FINA in submitting proposals for opening pre-bankruptcy proceedings}

The proposal to open a PP is authorized to be submitted by the debtor or the creditor, if the debtor agrees with the proposal (consent must be submitted with the proposal) (Art. 25 of the BA). Bearing in mind that initiating this procedure is a right not a duty, the reason for initiating is threatening insolvency, therefore, if the court acquires the belief that the debtor will not be able to fulfil his forthcoming

14 Official Gazette No. 105/15. 
obligations upon their maturity. One of the three presumptions is that the debtor has one or more recorded unexecuted payment bases in the Register of Order of Payment Bases kept by FINA, which should have been collected from any of his accounts on the basis of valid payment bases without further consent (Art. 4, par. 2 of the BA). The existence of this circumstance is proved by a certificate from FINA, which is obliged to issue such a certificate without delay at the request of the debtor or the creditor. Otherwise, FINA is liable for the damage that the applicant might suffer as a result (Art. 4, par. 3 of the BA).

\subsubsection{The role of FINA in opening pre-bankruptcy proceedings}

In case the court finds that the preconditions for opening the PP have been met, it will issue a decision on opening this procedure in which it will appoint a commissioner, if it deems it necessary, and will publish it on the courts' e-bulletin board website (Art. 33. of the BA). The decision on the opening of the PP will be submitted by the court to FINA (Art. 34, par. 5 of the BA). The decision must contain precisely specified data (Art. 34 of the BA). The creditors then report their claim to the competent FINA unit on the prescribed form and enclose in the transcript the documents from which the claim arises, i.e. which proves it. The 2017 amendment extended the deadlines set by the court in the decision on opening PP, so now the deadline for filing a claim in PP settlement proceedings is 21 days from the delivery of that decision on opening proceedings, and creditors can within 15 days submit statements on the reported claims of the debtor and the trustee, if appointed, to challenge the reported claims that they consider non-existent, with the obligatory indication of the amount for which the claim is disputed and the reasons for the dispute. The deadline for filing claims has been extended, so it is now determined that the decision to open PP proceedings contains an invitation to the debtor and the trustee, if appointed, to submit a written statement to the competent FINA unit within 30 days of delivery of the table of claims, a statement of whether the claim is acknowledged or disputed, with an indication of the amount for which the claim is contested and the reasons for the dispute. In doing so, FINA is entitled to reimbursement of actual costs, the type and amount of which are prescribed by the Ordinance on the type and amount of reimbursement of costs of the FINA in pre-bankruptcy proceedings and on the amount of reimbursement of costs of the FINA. ${ }^{15}$ Reimbursement of actual costs will be paid from the advance funds that the applicant is obliged to pay for the costs of PP in the amount of HRK 5,000 (Art. 28 of the BA). Ultimately, the indicative method of fact-finding indicates that FINA costs are likely to lead to a

15 Official Gazette No. 106/15. 
more expensive process. The legal consequences of opening a PP occur when the opening decision is published on the court's $e$-bulletin board and affect all creditors' claims arising before the opening of the proceedings, except for the rights of separate and exclusive creditors and claims of workers and former debtors and security measures from criminal proceedings and tax proceedings for determining the abuse of rights (Art. 65 of the BA). The Novelty from 2017 amendment the rules concerning separate and exclusive creditors and states that they are obliged to notify the competent FINA unit within the deadline for filing a claim of their rights, legal basis and part of the debtor's property relating to their separate right and give a statement as to whether or not they waive the right to separate settlement. This statement may be revoked by separate and exclusive creditors no later than the beginning of the hearing on the restructuring plan if the restructuring plan reduces their rights or the exercise of their rights is changed after the given statement. The relevant notices and statements are submitted on the form for filing a creditor's claim in pre-bankruptcy proceedings. One of the consequences is that FINA ceases to execute all bases for payment recorded in the Register, except for the calculation of unpaid salary, salary compensation and severance pay and the basis for payment related to security measures in criminal proceedings (Art. 69 of the BA). The debtor and the trustee (if appointed) are required to recognize or not claims within eight days from the expiration of the deadline for applications for reported creditors' claims, and creditors may contest the reported claims of another creditor. On the basis of these disputes, FINA compiles a table of reported and a table of disputed claims, which publishes and submits all documentation electronically to the court (Art. 41-43 of the BA).

\subsubsection{FINA's role in the procedure for confirming the pre-bankruptcy agreement or in the procedure for denying and suspending the pre-bankruptcy agreement}

After the hearing to examine the claim and the hearing where the restructuring plan is discussed and voted on, the Court issues a decision confirming the pre-bankruptcy agreement or the certificate is denied and the PP proceedings are suspended. In the event that the decision confirming the PP agreement becomes final, the court will also submit it to FINA. From the date of receipt of the final decision confirming the pre-bankruptcy agreement, FINA will not continue to enforce the funds on the debtor's account on the basis of payment grounds which it has ceased to execute since receiving the decision to open PP proceedings (Art. 71 , par. 1 of the BA). However, from the date of receipt of the final decision to suspend the PP proceedings, FINA will continue to enforce the funds on the debtor's account on the basis of the payment basis which it ceased to receive from 
the receipt of the PP decision (Art. 71, par. 1 of the BA). In cases of suspension of PP proceedings, the court will ex officio continue the proceedings as if a proposal for opening bankruptcy proceedings had been submitted, unless it finds that the debtor is fit to pay and has fulfilled all obligations to creditors (Art. 64. par. 2 of the BA).

\subsection{The role of FINA in bankruptcy proceedings}

The bodies of bankruptcy proceedings are the court, the bankruptcy trustee, the creditors 'assembly and the creditors' committee (Art. 75 of the BA). There were no significant changes regarding the court's authority, except that instead of the court, the creditors' committee approves the estimate of the costs of the bankruptcy proceedings (Art. 98, par. 2 of the BA), and the court approves the payment (Art. 76 of the BA). Thus, FINA is not a body of procedure but only and exclusively a participant as in the case of PP, but with narrowed powers and duties.

\subsubsection{The role of FINA in submitting proposals for opening bankruptcy proceedings of a legal entity and securing funds to cover the costs of bankruptcy proceedings}

In addition to the rules on the authorization of debtors and creditors to file for bankruptcy, one of the most important in this context is the obligation of FINA to file for bankruptcy, if the legal entity has unfulfilled bases for uninterrupted payment in the Register of Basis of Payment Order in period of 120 days (Art. 110, par. 1 of the BA). In this case, the court may issue a decision on the opening of bankruptcy proceedings without conducting preliminary proceedings (Art. 116, par. 1, of the BA). In accordance with the provisions of the aforementioned Ordinance on the type and amount of reimbursement of FINA's costs, it is entitled to reimbursement of costs in the amount of HRK 140.00 plus value added tax. This cost has the status of a creditor of the bankruptcy estate since it represents the cost of bankruptcy proceedings (Art. 110, par. 5 and 6 of the BA). It is also important to mention that FINA is not subject to the rule that the applicant for the opening of bankruptcy proceedings is obliged to pay an advance of HRK 1,000.00 to the Bankruptcy Fund and that by court order within eight days the additional amount of advance that cannot be higher than HRK 20,000.00 (Art. 114 par. 3 of the BA). Furthermore, as the settlement of the costs of bankruptcy proceedings is a special problem, it was determined that the Fund for the settlement of costs of bankruptcy proceedings is established in each court, and that the funds are provided on the basis of the rules of the BA. The procedure for securing funds to cover the costs of the bankruptcy procedure has been elaborated in detail in BA. 
It is stipulated that FINA, after determining the impossibility of execution of the basis for payment due to lack of funds in the accounts of the debtor of the legal entity, will order the bank to seize funds from the debtor's account, in the amount of HRK 5,000.00 for advance payment of bankruptcy proceedings (Art. 112. par. 1 of the BA). The order to confiscate funds is executed before other orders, except for the order for execution of the basis for payment of the employer's calculation of non-payment of the due amount of salary and salary compensation (Art. 112, par. 2 of the BA). If FINA seizes an amount sufficient to settle all outstanding payment bases entered in the Register of Order of Payment Bases, it will suspend further seizures for the amount of the advance for settling the costs of bankruptcy proceedings, release the seized funds and issue an order to banks to execute payment bases in Register of the order of the basis for payment, unless FINA is on the basis of the provision of Art. 110, par. 1 of this Act submitted a proposal for the opening of bankruptcy proceedings (Art. 112, par. 3 of the BA). After the execution of all unexecuted bases for payment, FINA will issue an order for the release of seized funds and allow the debtor to dispose of it (Art. 112, par. 4 of the $\mathrm{BA})$. Immediately after receiving the proposal to open bankruptcy proceedings, the court will request from FINA a notice on securing funds to cover the costs of the bankruptcy proceedings (Art. 112, par. 5 of the BA). By deciding to open bankruptcy proceedings against the debtor legal entity, the court will order FINA to order the bank to transfer the seized advance amount to the court account and suspend further seizure if the advance amount has not been seized in full (Art. 112 , par. 6 of the BA). If the court rejects or deny the proposal to open bankruptcy proceedings, the decision on rejection or denial will order FINA to release the seized funds (Art. 112, par. 7 of the BA).

\subsubsection{The role of FINA in abbreviated bankruptcy proceedings}

From the mentioned regular bankruptcy, one should distinguish the, so-called, abbreviated bankruptcy proceedings (Art. 428-436 of the BA). These rules stipulate that FINA will submit a proposal to open an abbreviated bankruptcy procedure if certain conditions are cumulatively met. Therefore, the obligation of the proposer to check the existence of the property has been abolished, which the previous proposer, the Ministry of Finance - Tax Administration, has been checking so far. Based on FINA's request, the court will publish an advertisement on the $e$-bulletin board after inspecting the court register, inviting persons authorized to represent the debtor to submit a notarized list of assets and liabilities to the court within 15 days of the announcement. Within 45 days from the publication of the announcement, creditor can also propose the opening of bankruptcy proceedings. If no one responds within these deadlines and no one advances the funds to 
cover the costs of the proceedings, the debtor will be considered insolvent and the court will issue a decision on opening and concluding an abbreviated bankruptcy proceeding. Otherwise, the court will suspend the shortened bankruptcy proceedings and, by appropriate application of the general provisions of the bankruptcy proceedings, issue a decision on initiating the preliminary proceedings, i.e. open the bankruptcy proceedings. The practice warns that due to the stated formalistic approach, a large number of entities that have property will be deleted, and it will not be controlled whether the debtors have ceded their property to rebuttal legal actions with the aim of damaging creditors. To avoid this problem, comparative experiences indicate a step-by-step approach due to the limited ability of courts to absorb a significant number of new bankruptcy proceedings. ${ }^{16}$

\subsubsection{The role of FINA in the process of liquidation of the bankruptcy estate}

The further role of FINA is highlighted in the rules on liquidation of the bankruptcy estate. Namely, the bankruptcy trustee is obliged, with appropriate application of the rules of enforcement proceedings, to submit to FINA without delay data on all real estate sold in bankruptcy proceedings, and on movables if their estimated value exceeds HRK 50,000.00 for entry in the Register of Real Estate and Movable Property, with an indication that they are being sold in bankruptcy proceedings (Art. 229, par. 3 of the BA). Therefore, the person who keeps the register of real estate and movables has changed because the same data were previously submitted to the Croatian Chamber of Commerce (HGK).

With regard to the rules on the sale of the debtor's property as a whole, it is stipulated that all announcements go through the $e$-bulletin board and that if the sale decision determines the sale by electronic public auction, the sale will be carried out with appropriate application of the enforcement rules (Art. 235, par. 2 and 3 of the BA). The court will confirm the decision on the sale with a decision if it finds that the sale does not put the creditors in a less favourable position for settlement than they would be if the debtor's property were liquidated in certain parts (Art. 235, par. 6 of the BA). Based on the decision on the sale and the final court decision confirming the decision on the sale, an advertisement will be published on the $e$-bulletin board website and on the FINAe website, indicating the conditions and manner of sale. The advertisement will indicate the place, time and manner of insight into the inventory of the bankruptcy debtor's property, the list of separate rights, evidence that the property belongs to the debtor, business books and documentation of the bankruptcy debtor and examination of the property (Art. 236, par. 1 of the BA).

16 Čuveljak, J., Komentar Stečajnog zakona, Narodne novine, Zagreb, 2018, p. 1166 et seq. 
Finally, there are new rules regarding the realization of cases on which there is a right of separation (Art. 247-256 of the BA). Namely, after the opening of bankruptcy proceedings, separate creditors are not authorized to initiate enforcement or insurance proceedings, and the terminated enforcement and insurance proceedings initiated by these creditors before the opening of bankruptcy proceedings will continue and be conducted by the court conducting bankruptcy proceedings. Therefore, this provision prescribes new procedural rules according to which separate creditors lose the right to initiate enforcement or insurance proceedings after the opening of bankruptcy proceedings, and prescribes the jurisdiction of the bankruptcy court to continue the terminated proceedings. This change in procedural rules is necessary in order to concentrate and speed up bankruptcy proceedings. The sale of real estate is carried out by FINA through an electronic public auction.

Unless the bankruptcy creditors have otherwise determined the manner and conditions of the sale at the reporting hearing, the debtor's property shall be sold by appropriate application of the provisions of Art. 247 and 249 of the BA (realization of objects on which there is a right of separation).

In all cases, the bankruptcy court and the bankruptcy trustee were given additional obligations, which objectively relieved the enforcement court in a large number of cases.

\subsubsection{The role of FINA in the process of selling real estate in bankruptcy}

Until the implementation of the new BA, the sale of real estate was usually done in two ways - by oral public auction or by direct agreement. Therefore, perhaps the biggest novelty is the rules for the sale of real estate in bankruptcy where the rules on the enforcement of real estate apply. It follows from the basic rules on the sale of real estate in bankruptcy that it is regularly sold according to the rules on liquidation of real estate in enforcement proceedings, which is why understanding the sale of real estate in enforcement proceedings is necessary to understand its sale in bankruptcy. Namely, when we talk about real estate as a subject of enforcement or part of the bankruptcy estate, then it can only be real estate which as a whole is determined by the rules governing ownership and other real rights, therefore, the principle of unity of real estate is accepted (Art. 9. of the ZOV). ${ }^{17}$

17 Law on Property and Other Real Rights, Official Gazette No. 91/96, 68/98, 137/99, 22/00, 73/00, 114/01, 79/06, 141/06, 146/08, 38/09, 153/09, 143/12, 152/14., hereinafter: ZOV. 
The sale and realization of real estate is carried out by sale at an electronic public auction (Art. 97, par. 1 of the EA) ${ }^{18}$ with the proviso that the rules on electronic public auction through FINA have been significantly changed. Therefore, the lex specialis regulation that was supposed to regulate the sale of real estate and movables in enforcement proceedings was abandoned, so what was supposed to be regulated by this regulation was included in the Enforcement Act, especially in its part entitled: Procedure for selling real estate in the Agency (Art. 132a-132i of the EA). Fr the subject at hand, quite important is the Ordinance on the manner and procedure of sale of real estate and movables in enforcement proceedings, ${ }^{19}$ which regulates all issues relevant to the implementation of the sale of movables and real estate at and by FINA.

FINA sells real estate on the basis of a court request for sale as a special type of document by which the court orders FINA to initiate the sale procedure and with the request submits a decision on enforcement, an excerpt from the land register and a conclusion on sale (Art. 95a, par. 2 of the EA). FINA has the same position as the bailiff (Art. 95a, par. 3 of the EA). In Art. 5. the Ordinance stipulates that the request for the sale of real estate in enforcement proceedings must contain a number of elements, and if it does not contain them, it is not complete. Consequently, there are cases when FINA will not act upon the request due to the impossibility of acting. Here, at least according to the doctrine, is the power of FINA to determine that it cannot act on a request for sale, in which case FINA is obliged to inform the competent authority and state the reasons why it considers it impossible to act. However, we consider it questionable whether FINA is allowed to do so. We hold, as analogies come out, similar situations in the notary's actions, that FINA should submit such a request to the court for a decision. Moreover, the jurisprudence raises the question of a situation in which FINA considers one thing and the competent court another, but due to the vagueness, the question arises as to how the foreclosure on the property will be carried out at all, whether the bailiff will have the opportunity to appeal and to whom. ${ }^{20}$

As the sale of real estate is now entrusted to FINA, this has significantly increased the costs of the sale itself, so creditors must be aware of the costs in question if they do not instruct the bankruptcy trustee on another method of sale (see Art. 229, par. 1 of the EA). In any case, FINA has the right to collect the costs that it will

18 Enforcement Act, Official Gazette No. 112/12, 25/13, 93/14, 55/16, 73/17, 131/20., hereinafter: EA.

19 Ordinance on the manner and procedure of sale of real estate and movables in enforcement proceedings, Official Gazette No. 156/14, 1/19., hereinafter: Ordinance.

20 Bodul, D., Vuković, A., (Još jedna) reforma stečajnog zakonodavstva funkcionalizacija stečajno pravne zaštite ili placebo efekt, Zbornik Pravnog fakulteta Sveučilišta u Rijeci, Vol. 36, No. 1, 2015, p. 181.213. 
have in connection with the sale of real estate from the advance to cover the costs to be paid by the creditor. Persons who have previously given a guarantee (Art. 99, par. 1 of the EA) and submitted an application for participation in an electronic public auction (Art. 132e, par. 1 EA) may participate as buyers in the auction. The guarantee can be expressed only in HRK and in accordance with the terms of sale. The bidder may access the electronic public auction system in person, but also through a proxy or legal representative. In practice so far, the question has been asked how to react to the actions of persons who, exempt from prior bail, join the sale process, offer the highest price and get their property awarded, but do not pay on time and thus prevent the sale of real estate without sanctions. Therefore, in the latest amendments, the legislator abolished the possibility of exemption from bail for the Republic of Croatia, municipalities, cities and counties and state bodies if they participate in the proceedings as a party (Art. 99 in conjunction with Art. 15, par. 2 of the EA). If the bidder would participate in the sale procedure through a proxy, then the power of attorney is stored in FINA (Art. 14 of the Ordinance). The jurisprudence indicates that this will require that one power of attorney exist for the court and the other power of attorney exist for FINA. In any case, after the payment of the guarantee, and when applying for participation in the auction, FINA assigns and delivers to the future bidder the, so-called, identifier under which he anonymously participates in the auction - submits his bid (Art. 132e, par. 3 of the EA). This means that for each auction the bidder must have a different identifier. If the bidder is represented by a proxy or legal representative, then the identifier is submitted to the proxy or legal representative (Art. 15 of the Ordinance). After the bidder pays the guarantee, the bidder will have visibility in the electronic public auction system the auctions for which he has paid the guarantee and for which he can fill in the application for participation in the electronic public auction. The return of the guarantee can only take place if FINA receives an order from the competent authority to return the guarantee, otherwise the guarantee will be on the account. After FINA receives the decision of the competent authority on the return of the guarantee, FINA is obliged to return the guarantee within 8 days to the account indicated in the application for participation (Art. 13 of the Ordinance). It is certainly important to mention the obligation of FINA to open special accounts with a commercial bank to which only: 1) purchase funds are paid in the execution of enforcement, 2) guarantee funds paid in the implementation of enforcement, will be deposited. Data on these accounts should be made public, provided that the commercial bank does not charge a fee for opening, maintaining and closing these special accounts. Nevertheless, anecdotal evidence, as well as the relevant provisions of the Payment Transactions Act, ${ }^{21}$ call

${ }^{21}$ Official Gazette No. 133/09, 136/12, 66/18. 
this provision into question. It is also the duty of FINA to transfer funds from these special accounts without delay on the basis of a court order, and if FINA finds it impossible to execute a court order, it must immediately inform the court from which it received the money transfer order. Funds on these special accounts are exempt from enforcement (Art. 132c of the EA). It is important to mention the deadlines within which FINA must act. It is thus stipulated that FINA may take action in the proceedings only on the basis of a court order and that the time elapsed before the delivery of the order to FINA is not counted within the statutory time limit for its taking. It was also determined that if the day for taking action in the procedure is determined by law as a holiday, i.e. a non-working day, the first working day will be taken as the day for taking action (Art. 132f, of the EA). In Art. 3 and 4 Ordinance regulates in more detail the issue of delivery of documents between FINA, the court and other competent bodies.

Now the sales hearings are structured as an electronic auction which, each, lasts ten working days during which time bids are collected (Art. 102, par. 3 of the EA). Bids for participation in the electronic auction are submitted under the identifier and contain the bid price (Art. 132g, par. $4 \mathrm{OZ}$ ), and are collected electronically (Art. 132g, par. 1 of the EA). No more identical bid prices may be given at the electronic public auction (Art. 132g, par. 5 of the EA). The bids themselves are collected electronically, on working and non-working days between 0-24 hours, provided that the date and time of the beginning of the bidding and the date and time of the end of the bidding are determined by FINA in the invitation to participate, and cannot be changed later (Art. 17 of the Ordinance). It is also possible for bids to be submitted in the FINA business unit, provided that this is possible only during its working hours, i.e. during the working hours of the branch office (Art. 18 of the Ordinance). In order to avoid a symbolic increase, it was decided to specify the step of price increase (so-called auction step) for which the bidder may submit a bid in relation to the amount of the minimum price for which the item can be sold or the amount of the last valid bid (Art. 19 of the Ordinance). In any case, the submission of bids in the electronic public auction is regulated in more detail, with the initial sale price determined by the court, and the increase of the last valid bid is possible only for a predetermined auction step (Art. 21 of the Ordinance).

BA prescribes the possibility of four hearings (Art. 247, par. 3, item 5 and par. 4 of the BA). If the first auction fails, when FINA does not receive any valid bid, the second one is approached and so on. If even the fourth auction fails, FINA informs the court in order to suspend the enforcement (Art. 102, par. 4 of the EA). The electronic auction will also be conducted if only one bidder participates in it (Art. 100 of the EA). In these actions, the bidder can choose between the pre- 
offered amounts offered by the electronic public auction system, so if no valid bid is recorded in the system, then the same can choose between the bid amount corresponding to the starting price of the subject of sale, auction step or an amount corresponding to a starting price increased by three initial steps. If a valid bid is recorded in the system, then the bidder can choose between the bid amount corresponding to the amount of the highest recorded valid bid increased by the auction step and the bid amount corresponding to the amount of the highest recorded valid bid increased by three auction steps. Each selection must be confirmed by the bidder with an advanced electronic signature (Art. 21 of the Ordinance). Invalid bids will not be shown at a later bid.

The Ordinance also regulates in more detail the issue of interruption, postponement and continuation of the sale of real estate and movables in enforcement proceedings (Art. 24). Thus, FINA will terminate the procedure for the sale of real estate and movables if it receives a decision from the competent authority to terminate the procedure, and it will continue such a procedure when it receives a decision from the competent authority to continue the procedure. The effect of the interruption is that all deadlines set for the sale implementation process cease to run, and with the continuation of the procedure, the deadlines start running again. As this is an electronic public auction, it is possible that due to technical reasons, the procedure will be interrupted. Therefore, the Ordinance determines the conduct of FINA after a break due to technical difficulties. Namely, if the bidding is to be suspended due to technical difficulties, FINA will then continue bidding after the difficulties have been resolved. In the event that difficulties arise and therefore the last day of the tender or the difficulties would last longer than 12 hours in one day of the tender, then the tender shall be extended by one day. FINA will put a notice on its website (Art.29). In the event that a decision on the postponement of enforcement is received from the competent authority, the procedure will continue when a decision on the continuation of the procedure is received from the competent authority. Unlike the termination of the proceedings, no action will be taken in the enforcement proceedings in the event of a stay. Both in case of suspension and in case of postponement of enforcement, after FINA receives the decision of the competent body to continue the procedure, it will re-publish the invitation to participate in the electronic public auction (Art. 24 of the Ordinance).

The electronic public auction shall end at a time specified in advance in the invitation to participate. After the completion of the electronic public auction, FINA informs the court about the conducted auction, collected bids and other necessary information (Art. 103, par. 2 of the EA). In doing so, a detailed report is submitted to the court stating all the information relevant to the decision on the 
sale. Upon receipt of the notice, the court determines which buyer offered the highest price and whether the preconditions for awarding him real estate have been met (Art. 103, par. 3 of the EA). The decision on the award is made in writing, published on the court's $e$-notice board and on the FINA website and it is considered that the decision is delivered to all persons to whom the conclusion of the sale is sent and to all participants in the auction on the third day after its display on the notice board. The decision on the award should contain a clause of finality (provided that in Art. 28, par. 2 of the Ordinance prescribes in detail what information must be contained in the settlement decision submitted to FINA), and if that decision does not have such a clause it will be returned to a competent authority. The decision on the award will specify the deadline within which the buyer is obliged to pay the purchase price to the FINA account, by informing the court of the payment (or the fact that the payment has not been made) within 8 days of the payment deadline. The purchase price is paid into a special account in FINA, with FINA transferring the funds at the moment when it receives an order from the court (Art. 106, par. 1 and 3 of the EA). FINA will return the guarantee on the basis of a court order for the transfer of funds to the bidders whose bid was not accepted (Art. 99, par. 4 of the EA).22

\subsubsection{The role of FINA in the so-called "Automatic bankruptcy"}

Finally, FINA based on the legal powers under Art. 444 of the BA, initiates "automatic bankruptcy" for 27,106 legal entities that on September 1, 2015 (the date of entry into force of the BA) in the Register of the order of payment had unfulfilled bases for payment in an uninterrupted period of 120 days (so-called "legally dead societies"). FINA submits to the court: a) a request for the implementation of abbreviated bankruptcy proceedings and b) a proposal for the opening of bankruptcy proceedings. These are "dead companies" that do not perform any activity for a long time, and for which the legislator assessed that it is most rational to permanently eliminate them from entrepreneurship. For submitting a request for the implementation of abbreviated bankruptcy proceedings and a proposal for opening bankruptcy proceedings for legal entities referred to in Art. 444 of the BA, FINA is not entitled to compensation (Art. 4 of the Ordinance).

Namely, exceptionally from the deadline from Art. 429, par. 1 of the BA, for legal entities that have unregistered bases for payment in an uninterrupted period of 120 days recorded in the Register of the order of payment bases, and who do not

22 For more, Kontrec, D., Ovrha na nekretnini, Hrvatska gospodarska komora - sektor za trgovinu, 23. forum poslovanja nekretninama, 2015; Mihelčić, G., u suradnji s Kontrec, D., Komentar Ovršnog zakona, Organizator, Zagreb, 2015, pp. 15-1150. 
have employees and the conditions for deletion from the court register ex officio are not met, FINA will submit a request to the competent court for the implementation of abbreviated bankruptcy proceedings within 8 days from the expiration of the period in which the conditions for initiating proceedings for the legal entity are met, by submitting a written submission to the competent commercial court. On the other hand, exceptionally from the deadline from Art. 110, par. 1 of the BA, for legal entities that have in the Register of payment orders recorded unexecuted bases for payment in an uninterrupted period of 120 days, FINA will submit to the competent court a proposal to open bankruptcy proceedings within 8 days the period in which the conditions for initiating proceedings have been met for the legal person, by submitting a written submission to the competent commercial court according to the seat of the legal person.

\section{INSTEAD OF A CONCLUSION (OR PERCEIVED POTENTIAL PROBLEMS OF FINA'S OPERATION IN (PRE)BANKRUPTCY PROCEEDINGS)}

The international spread of the coronavirus is not only generating dramatic consequences from a social perspective but it is also heavily affecting the global economy. Bankruptcy and bankruptcy regulations could be said to be one of the basic parts of modern market systems today. ${ }^{23}$ For this reason, governments, financial regulators and international organizations are responding to the coronavirus with a package of legal, economic and financial measures. Among the legal responses included in these packages, many countries, such as Australia, Belgium, Colombia, Czech Republic, France, Germany, Luxembourg, India, Italy, New Zealand, Peru, Poland, Portugal, Russia, Singapore, Spain, the United Kingdom, and the United States, have proposed or implemented temporary changes to their insolvency frameworks. ${ }^{24}$

23 Edward R.; Morrison E. R.; Saavedra, A. C., Bankruptcy's Role in the COVID-19 Crisis, Columbia Law School, 2020, 6-7, available at [https://papers.ssrn.com/sol3/ papers.cfm?abstract_id=3567127], Accessed 01 May 2021.

24 Gurrea-Martínez, A., Insolvency Law in Times of COVID-19, The Company Lawyer, Vol. 41, No. 7, 2020, p. 191-198. For an overview of the policy responses adopted by national legislators, see more on [https://www.imf.org/en/Topics/imf-and-covid19/Policy-Responses-to-COVID-19] and [https:// som.yale.edu/faculty-research-centers/centers-initiatives/program-on-financial-stability/covid-19- crisis], Accessed 02 May 2021. For an analysis of the responses implemented by financial regulators and supervisors, see [https://www.iif.com/covid-19] and Remolina, N., Financial Regulators' Responses to COVID/19, IBEROAMERICAN INSTITUTE FOR LAW AND FINANCE, WORKING PAPER 1/2020 (available at [https://papers.ssrn.com/sol3/papers.cfm?abstract_id=3554557] Accessed 03 May 2021. 
However, it must be pointed out that the issue of bankruptcy proceedings in countries with a long market tradition is a dynamic area in which new solutions are sought that will follow the trend of change in the international economy. The World Bank Principles and the UNCITRAL Legislative Guide ${ }^{25}$ have highlighted the importance of informal arrangements for restructuring. Both texts treat informal debt restructuring as an integral part of an efficient creditor-debtor regulatory system. Therefore, there are many questions and doubts that arise in world practice and expert considerations regarding the construction and application of bankruptcy legislation.

One of the questions is, should the Law favour out-of-court (informal) arrangements or formal reorganization processes under the auspices of the court? An out-of-court restructuring or workout is a contract between the debtor and its creditors, which binds the debtor vis-à-vis the creditors and also binds the creditors There are a variety of explanations for the widespread use of informal contractual workouts, but the need for flexibility, as opposed to the relative rigidity of the formal insolvency proceedings, is probably the most important one. Also, it would be incorrect to assume that informal workouts are always superior to formal insolvency proceedings. The disadvantages of workouts vis-à-vis formal procedures are connected with the effects that characterize these procedures. If the debtor situation requires certain specific effects, such as a stay on creditor actions that provides some breathing space from collection efforts, or the repeal of executory contracts, a formal insolvency procedure may be the only viable option. ${ }^{26}$ Moreover, comparative research shows that there are different understandings in procedural doctrine and legislation about the legal nature of bankruptcy proceedings. Different treatment, as judicial or as an administrative method of legal protection, has led to the fact that modern legal systems today are offering different conceptions of bankruptcy that oscillate between a concept similar to court decision-making, on the one hand, and purely administrative methods, on the other and there are several different transitional or combined models. ${ }^{27}$ The experience from both the 2008 global financial crisis and also Asian financial crisis

25 World Bank Symposium, Building effective insolvency system - transcript, Washington, D.C., 2016., available on: [www.wordlbank.org] Accessed 10 March 2021 and UNCITRAL, Legislative Guide on Insolvency Law, 2016., available on: [www.uncitral.org] Accessed 10 March 2021.

26 Gurrea-Martínez, A., The Future of Reorganization Procedures in the Era of Pre-Insolvency Law, European Business Organization Law Review, Vol. 21, No. 4, 2020, p. 829-854.

27 Bodul, D., Bankruptcy Policy, State Attitude towards Bankruptcy and State Interventionism, Economic and Social Development - 16th International Scientific Conference on Economic and Social Development -"The Legal Challenges of Modern World", Varazdin Development and Entrepreneurship Agency in cooperation with Faculty of Law, University of Split and University North, Book of Proceedings, 2016, pp. 273-282. 
illustrates the importance of having informal workout frameworks setting out the core obligations for informal debt negotiations with financial institutions, such as a standstill agreement preventing debt enforcement. ${ }^{28}$ As they are informal tools, these frameworks can be put in place relatively quickly, ideally spear-headed by the country's central bank and bankers' association, and they typically avoid the procedural complexities and timelines of court proceedings. Creditors should be incentivized to restructure debts (for instance, through tax incentives) and use all restructuring tools available in order to save viable businesses while also maximizing their recovery. As a medium-term measure, countries should aim to put preventive restructuring or pre-insolvency frameworks in place to facilitate debt restructuring as early as possible. ${ }^{29}$

From the Croatian perspective, it is evident that the problem of payment of due financial obligations in the economy has not been completely eliminated, which means that (bankruptcy) courts will continue to fight with a large number of cases, so the idea of restructuring outside and before bankruptcy, which would make the debt sustainable and adjust the business to new circumstances, is gaining special importance in the Republic of Croatia as well. For now, the indicative method of establishing the facts indicates that these processes of dejudicialization of the protection of civil rights and obligations in Croatia are more a reflection of opportunistic, potentially unconstitutional solutions, and less thoughtful systemic legalist interventions. Namely, in the ZFPPN, in the part related to the pre-bankruptcy settlement procedure, FINA conducted the first part of the procedure according to the rules of administrative procedure through the settlement council, while the commercial court verified in the court procedure who voted for the pre-bankruptcy settlement proposal. However, in Croatian law, bankruptcy proceedings are traditionally court proceedings in the actual jurisdiction of commercial courts. Moreover, from a doctrinal perspective, it can be stated that the objective needed for specialization of courts is a necessary result of the requirement for effective judicial protection. Thus, judicial jurisdiction in this proceeding is the result of the aspiration to achieve fairness in terms of equal settlement of creditors from the debtor's property. Therefore, in the new BA, which entered into force on September 1, 2015, FINA "lost" all functions of conducting proceedings and is now acting as a service for pre-bankruptcy and bankruptcy proceedings. Moreover, analysing the legislative history of the adoption of the ZFPPN, it is shown that there was no consensus of the profession on not only the adoption,

28 Ricardo Caballero, J., R., et al., Zombie Lending and Depressed Restructuring in Japan, American Economic Review, Vol. 98, No. 5, 2008, p. 1943-1977.

29 For a detailed discussion of crisis response see, World Bank Group FCI Unit, Accessing the impact and policy response in support of private sector firms in the context of the COVID-19 pandemic, 2020. 
but also the implementation of these regulations. At one practical and empirical level, problems are still present, and we will give two examples. The first is the sale of real estate in bankruptcy, which occupies a very important place in the reform of the BA, which is in line with the general property and economic significance of real estate (as a rule that the most valuable parts of the debtor's property whose ownership can be relatively easily determined and proven). Unless the bankruptcy creditors have otherwise determined the manner and conditions of the sale at the reporting hearing, the debtor's assets are sold by FINA through an electronic public auction, with appropriate application of the rules of enforcement proceedings. For now, part of the doctrine and practice, believes that the process of selling real estate is complex and formalized, and even burdened with a series of unnecessary steps or decisions that must be made by the competent authorities during the procedure. ${ }^{30}$ Therefore, they are sceptical, even of expectations that the reforms will be counterproductive, believing that, instead of relieving the burden, the courts could have a lot of work to do in bankruptcy cases. To this they add the fact that the text of the old BA was not significantly criticized in terms of real estate sales, so they also raise the question of the expediency of more comprehensive changes in this part of the BA. Furthermore, another example shows that in practice often the bankruptcy estate is not enough to pay the costs of the proceedings, so the legislator decided to provide funds in advance to cover them, by prescribing that the FINA after determining the inability to execute the basis for payment due to lack of cash funds on the accounts of the debtor of the legal entity, order the bank to seize the funds from the account of the debtor, in the amount of HRK $5,000.00$ for an advance to cover the costs of the bankruptcy proceedings. In the provisions of Art. 112, par. 2-7. of the BA, the procedure in these cases is further elaborated. But here the fundamental question arises, how is it possible to seize funds to ensure the costs of bankruptcy proceedings in a case where the existence of some bankruptcy reason has not yet been established by court? In any case, the outbreak of COVID-19 triggered an economic contraction of unprecedented depth and synchronization. Economic activity and trade fell sharply in the first half of 2020 as countries across the globe introduced measures to contain the pandemic. Special, temporary out-of-court restructuring mechanisms can facilitate the restructuring of viable enterprises without overwhelming the court system. However, court-led insolvency procedures are also necessary to allow for the reorganization of viable enterprises that require more extensive restructuring. But the question remains - does the role of FINA in informal restructuring mechanism increasing or decreasing the capacity of insolvency systems?

$30 \quad$ Kontrec, op. cit., note 22. 


\section{REFRENCES}

\section{BOOKS AND ARTICLES}

1. Blanchard, O.; Philippon, T.; Pisani-Ferry, J., A New Policy Toolkit Is Needed as Countries Exit COVID-19 Lockdowns, Peterson Institute for International Economics (PIIE) 20-8, June, 2020

2. Bodul, D., Bankruptcy Policy, State Attitude towards Bankruptcy and State Interventionism, Economic and Social Development - 16th International Scientific Conference on Economic and Social Development -“The Legal Challenges of Modern World”, Varazdin Development and Entrepreneurship Agency in cooperation with Faculty of Law, University of Split and University North, Book of Proceedings, 2016, pp. 273-282

3. Bodul, D., Grbić, S., O međusobnoj komplementarnosti pojmova „sud“ i „javni bilježnik“ u praksi Europskog suda za ljudska prava, Javni bilježnik, No. 2, 2014

4. Bodul, D., Vuković, A., (Još jedna) reforma stečajnog zakonodavstva funkcionalizacija stečajno pravne zaštite ili placebo efekt, Zbornik Pravnog fakulteta Sveučilišta u Rijeci, Vol. 36, No. 1, 2015, p. 181.-213

5. Boggs, P., Impact of COVID-19 on Insolvency Laws: How Countries Are Revamping Their Insolvency and Restructuring Laws to Combat COVID-19, 2020

6. Čuveljak, J., Komentar Stečajnog zakona, Narodne novine, Zagreb, 2018

7. Dika, M., Insolvencijsko pravo, Pravni fakultet, Zagreb, 1998

8. Eraković, A., Stečajni zakon s komentarom i primjerima, Računovodstvo, revizija i financije Plus, Zagreb, 1997

9. Group of Thirty, Reviving and Restructuring the Corporate Sector Post-Covid: Designing Public Policy Interventions, Group of Thirty, Washington D.C. Marsh, 2020

10. Gurrea-Martínez, A., Insolvency Law in Times of COVID-19, The Company Lawyer, Vol. 41, No. 7, 2020, p. 191-198

11. Gurrea-Martínez, A., The Future of Reorganization Procedures in the Era of Pre-Insolvency Law, European Business Organization Law Review, Vol. 21, No. 4, 2020, p. 829-854

12. Hodbod, A.; Hommes, C.,; Hube, S. J., Salle, I., Avoiding zombification after the COVID-19 consumption game-changer, VoxEU.org, 21 December, 2020

13. Kontrec, D., Ovrha na nekretnini, Hrvatska gospodarska komora - sektor za trgovinu, 23. forum poslovanja nekretninama, 2015

14. Mihelčić, G., u suradnji s Kontrec, D., Komentar Ovršnog zakona, Organizator, Zagreb, 2015

15. Ministry of Law Singapore, Simplified Insolvency Programme, October 5, 2020

16. Omejec, J., Konvencija za zaštitu ljudskih prava i temeljnih sloboda u praksi Europskog suda za ljudska prava, strasbourški acquis, Zagreb, Novi informator, 2013

17. Ricardo Caballero, J., R., et al., Zombie Lending and Depressed Restructuring in Japan, American Economic review, Vol. 98, No. 5, 2008, p. 1943-1977

18. UK Government, Corporate Insolvency and Governance Bill 2020: factsheets, UK Government Department for Business, Energy and Industrial Strategy (BEIS) and The Insolvency Service, June 1, 2020 
19. World Bank Group FCI Unit, Accessing the impact and policy response in support of private sector firms in the context of the COVID-19 pandemic, 2020

20. Wyman, O., Building up immunity of the financial sector: Policy actions to address rising credit risk and preserve financial stability, August 2020

\section{ECHR}

1. Convention for the Protection of Human Rights and Fundamental Freedoms with Protocols, Official Gazette No. 18/97, 6/99, 14/02, 13/03, 9/05, 1/06, 2/10

2. ECHR, Interfina and Christian della Faille d'Huysse v. Belgium, decision, 4 May 1987, no. $11101 / 84$

3. ECHR, Ceteroni v. Italy, judgment, 15 November 1996, Reports of Judgments and Decisions $1996-\mathrm{V}$

4. ECHR, Bassani v. Italy, judgment, 11 December 2003, no. 47778/99

5. ECHR, Capital Bank AD v. Bulgaria, Judgment, 24 November 2005, no. 49429/99

6. ECHR, Sukobljević v. Croatia, Judgment, 2 November 2006, no. 5129/03

7. ECHR, S.p.r.l. ANCA and Others v. Belgium, decision, 10 December 1984, Decisions and Reports 40

\section{LIST OF NATIONAL REGULATIONS, ACTS AND COURT DECISIONS}

1. Bankruptcy Act, Official Gazette No. 71/15, 104/17

2. Civil procedure Act, Official Gazette No. 53/91, 91/92, 112/99, 88/01, 117/03, 88/05, 2/07, 84/08, 96/08, 123/08, 57/11, 148/11, 25/13, 89/14, 70/19

3. Decree on Criteria and Manner of Calculating and Paying Remuneration to Bankruptcy Trustees, Official Gazette No. 105/15.

4. Enforcement Act, Official Gazette No. 112/12, 25/13, 93/14, 55/16, 73/17, 131/20.

5. Law on Courts, Official Gazette No. 28/13, 33/15, 82/15, 82/16, 67/18, 126/19, 130/20

6. Law on Financial Agency, Official Gazette No. 117/01, 60/04, 42/05.

7. Law on Financial Operations and Pre-Bankruptcy Settlement, Official Gazette No. 108/12, $144 / 12,81 / 13,112 / 13,71 / 15,78 / 15$.

8. Law on Property and Other Real Rights, Official Gazette No. 91/96, 68/98, 137/99, 22/00, 73/00, 114/01, 79/06, 141/06, 146/08, 38/09, 153/09, 143/12, 152/14.

9. Ordinance on the list of Financial Agency units and areas of their competence, Official Gazette No. 106/15.

10. Ordinance on the manner and procedure of sale of real estate and movables in enforcement proceedings, Official Gazette No. 156/14, 1/19.

11. Ordinance on the type and amount of reimbursement of costs of the Financial Agency in pre-bankruptcy proceedings and on the amount of reimbursement of costs of the Financial Agency, Official Gazette No. 106/15.

12. Payment Transactions Act, Official Gazette No. 133/09, 136/12, 66/18. 


\section{WEBSITE REFERENCES}

1. Edward R. Morrison; E. R., Saavedra, A. C., Bankruptcy's Role in the COVID-19 Crisis, Columbia Law School, 2020, 6-7, available at [https://papers.ssrn.com/sol3/papers. cfm?abstract_id=3567127], Accessed 01 May 2021

2. [https://www.imf.org/en/Topics/imf-and-covid19/Policy-Responses-to-COVID-19] Accessed 02 May 2021

3. [https://som.yale.edu/faculty-research-centers/centers-initiatives/program-on-financial-stability/covid-19- crisis], Accessed 02 May 2021

4. Remolina, N., Financial Regulators' Responses to COVID/19, IBEROAMERICAN INSTITUTE FOR LAW AND FINANCE, WORKING PAPER 1/2020, available at [https:// papers.ssrn.com/sol3/papers.cfm?abstract_id=3554557], Accessed 03 May 2021

5. UNCITRAL, Legislative Guide on Insolvency Law, 2016, available at [www.uncitral.org], Accessed 10 March 2021

6. World Bank Symposium, Building effective insolvency system - transcript, Washington, D.C., 2016, available at [www.wordlbank.org] Accessed 10 March 2021

7. [https://www.iif.com/covid-19], Accessed 03 May 2021 